\title{
Opportunities in recycling AAC waste as aggregate for lightweight concrete
}

OLIVÉr FENYVESI - BME Department of Construction Materials and Technologies

- fenyvesi.oliver@epito.bme.hu

BENCE JANKUS - BME Faculty of Architecture - bence.jankus@gmail.com

Érkezett: 2015. 04. 08. - Received: 08. 04. 2015. " http://dx.doi.org/10.14382/epitoanyag-jsbcm.2015.11

\section{Abstract}

The conscious waste handling is getting more important world-wide. In the past fifteen years several detailed decrees and regulations were issued, dealing with this topic. The independent category of industrial waste of the construction industry is about 15-years old as well. In our research, the opportunities in recycling autoclaved aerated concrete (AAC) waste were investigated. AAC is a rather young building material, compared to the ancient ones, e.g. concrete, wood, or natural stone. The first factory, producing this material, was founded in 1929, in Sweden, and the first one in Hungary in 1963 (at Kazincbarcika). The following question has been raised: What is going to happen with the large amount of AAC building elements (mainly in family houses) when they reach their design lifetime, and are to be demolished, creating AAC waste? In our research, different ways for recycling this material were investigated. Our theories were confirmed by laboratory tests. Our ultimate task was to develop some new, useful concrete products, made from AAC waste. In the past 3 years, two research phases were finalized, both for different purposes of use. In the first phase, load bearing and insulating lightweight concrete mixtures with crushed AAC aggregate have been made. In the second phase, the mixtures were designed for vertical covering applications. Laboratory tests were made according to European and Hungarian standards.

Keywords: Autoclaved aerated concrete (AAC), cellular concrete, building industrial waste, recycling, lightweight aggregate concrete (LWAC)

\section{Introduction}

Waste-handling is a term, which has higher and higher importance in both jurisprudence and technical science. The first EU regulation, which has dealt with the topic in-detail, was published in 2000 [1]. The Hungarian government took this EC decision as a base to issue the first detailed national decree about building industrial waste, after joining the European Union in 2004 [2]. The operative regulation [3] contains both compulsions and concessions. Today it is compulsory to use recycled building materials above a limited investment value (defined in the regulation). However, many extra terms and financial support can be received in procurement processes, according to green considerations. Due to this, several research were targeted to study the recycling of communal and industrial wastes in Hungary as well $[4,5,6]$. About lightweight aggregate concrete (LWAC) made with crushed autoclaved aerated concrete (AAC) there have been few researches published yet, but there were some successful e.g. for clinker production [7], and in testing of traditional screed for floorings [8], or stabilized sand insulating concrete [9].

Our research was started at the Budapest University of Technology and Economics, Department of Construction Materials and Technologies in 2012. When looking for a topic for our research, our main aim was to choose some building material that is well-known world-wide, however, only few researches are dealing with its recycling opportunities. AAC perfectly met these requirements. This young building material is produced since less than a hundred years. The first buildings, made of its earlier version (aerated concrete, AC) are about to reach their design lifetime, therefore, large amount of $\mathrm{AC}$ waste can be expected to appear in the next decade. Recycling options should to be developed, supported by laboratory tests and results. This is the first step to give a new product that can be applied in the construction industry.

\section{Experimental studies}

In the last three years two different research phases were completed in our laboratory - both for different purposes of use. In the first phase, load bearing and insulation LWAC mixtures were made. In the second phase, the mixtures were designed for vertical covering applications. Detailed information about the design parameters, and the test results are given in Table 1.

The mixtures, made in the first research phase (load bearing and insulation purpose), were tested according to European standards for apparent (body) density, compressive strength (EN 12390-3), watertightness (EN 12390-8) and thermal conductivity (ISO 8302). The mixtures, designed for vertical covering purpose (second research phase) were treated and tested as artificial stone. Apparent (body) density, compressive strength (EN 14617-15), flexural-tensile strength (EN 146172), impact resistance (EN 14617-9), freeze-thaw resistance (EN 14617-5) and thermal conductivity (ISO 8302) were studied.

The type and the dosage of the used cement were chosen depending on the planned application. For the load bearing mixtures, a CEM III was chosen - our primary target was cost and ecological effectiveness. The mix design of LWAC targeted to provide paste saturated mix [10]. In the second research phase, when the mixtures were designed for covering purpose, the top priority was aesthetical appearance. For this purpose CEM I type was chosen and coloring pigments were added 
to the mixtures as well. The dosage was planned according to reference recommendations [11] [12] [13].

We prepared the AAC waste for suitable aggregate to lightweight concrete by a jaw crusher. After one crushing period, particle size distribution was tested. The results showed that the produced particle size distribution is in the II. quality class according the recent Hungarian regulations (MSZ 4798) (Fig. 1), therefore it is suitable for concrete aggregate without any addition of conventional aggregate. In the first research phase we used this one-phase-crushed bulk as lightweight aggregate. The maximum particle size was $16 \mathrm{~mm}$. In the second research phase, to reach the highest compressive strength possible with the selected cement dosage, the bulk was sieved into six, sharp graded fractions $(0 / 0,25 \mathrm{~mm} ; 0,25 / 1,0 \mathrm{~mm} ; 1 / 2 \mathrm{~mm} ; 2 / 4 \mathrm{~mm}$; $4 / 8 \mathrm{~mm} ; 8 / 16 \mathrm{~mm}$ - Fig. 2). The fractions were added into the mixtures according to limit grading curve $\mathrm{B}$ according the recent Hungarian regulations (MSZ 4798).

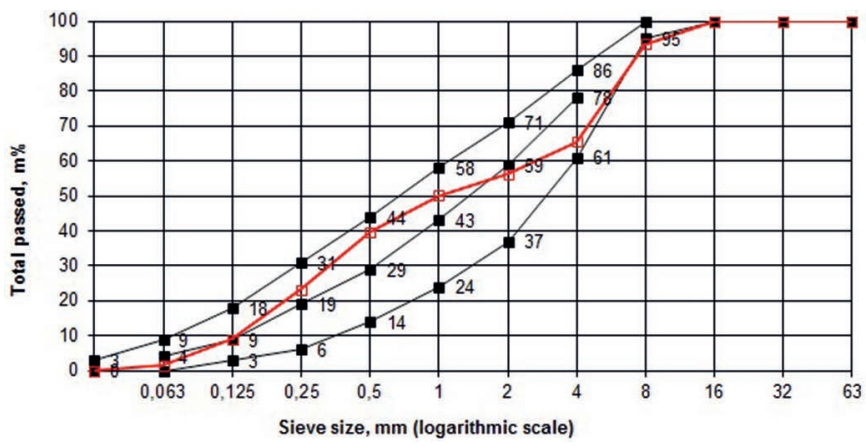

Fig. 1. Particle size distribution curve

1. ábra Szemeloszlási görbe

After a half year of storage, map surface cracking of the specimens was observed, made in the first research phase. For this reason, we decided to add PP fiber addition to the mixtures in the second phase, to prevent the formation of shrinkage cracks on the surface of the specimens [11] [12] [13]
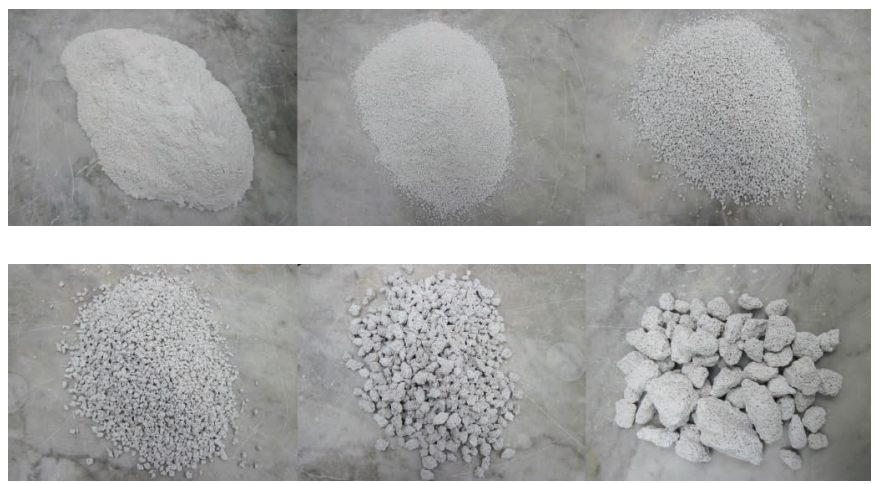

Fig. 2. Sieved aggregate frections

2. ábra Szitált adalékanyag frakciók

\section{Discussion}

\subsection{First research phase - general}

According to the test results of the first research phase, it can be postulated that the tested mixtures can be applied as vertical load bearing structures of a multi-level building. Based on the compressive strength results, we recommend using the designed mixtures in building blocks (Table 1). The masonry mortar, necessary for walling, can be manufactured from the AAC waste (with fractions under grain size of $1 \mathrm{~mm}$ ) as well. According to our watertightness test results, the mixtures can be applied to subsoil parts of such buildings as well - this is an advantage to other common blocks, which are available on the market.

\begin{tabular}{|c|c|c|c|}
\hline & \multirow[t]{2}{*}{$1^{\text {st }}$ research phase } & \multicolumn{2}{|c|}{$2^{\text {nd }}$ research phase } \\
\hline & & $1^{\text {st }}$ mixing stage & $2^{\text {nd }}$ mixing stage \\
\hline $\begin{array}{l}\text { Grain size distribution } \\
\text { (MSZ 4798) }\end{array}$ & Class II (MSZ 4798) & Curve B (MSZ 4798) & Curve B (MSZ 4798) \\
\hline Cement type & CEM II B-S $42.5 \mathrm{~N}(\mathrm{~V})$ & CEM I 52.5 N (grey) & CEM I $52.5 \mathrm{~N}$ (white) \\
\hline Cement dosage & $500-650 \mathrm{~kg} / \mathrm{m}^{3}$ & $350-450 \mathrm{~kg} / \mathrm{m}^{3}$ & $350-450 \mathrm{~kg} / \mathrm{m}^{3}$ \\
\hline Water-to-cement ratio & 0.55 & 0.4 & 0.4 \\
\hline PP fibers & - & $1.5 \mathrm{~kg} / \mathrm{m}^{3}$ & $1.5 \mathrm{~kg} / \mathrm{m}^{3}$ \\
\hline Coloring & - & $5 \mathrm{~m} \%$ (to cement) & 5 m\% (to cement) \\
\hline Apparent (body) density & $1380-1450 \mathrm{~kg} / \mathrm{m}^{3}$ & $1250-1350 \mathrm{~kg} / \mathrm{m}^{3}$ & $1250-1350 \mathrm{~kg} / \mathrm{m}^{3}$ \\
\hline $\begin{array}{l}\text { Compressive strength } \\
\text { (EN 12390-3, EN 14617-15) }\end{array}$ & $12-16 \mathrm{~N} / \mathrm{mm}^{2}$ & $6-9 \mathrm{~N} / \mathrm{mm}^{2}$ & $2.5 \mathrm{~N} / \mathrm{mm}^{2}$ \\
\hline $\begin{array}{l}\text { Thermal conductivity } \\
\text { (ISO 8302) }\end{array}$ & $0.39-0.45 \mathrm{~W} / \mathrm{mK}$ & $0.28-0.36 \mathrm{~W} / \mathrm{mK}$ & $0.28-0.36 \mathrm{~W} / \mathrm{mK}$ \\
\hline $\begin{array}{l}\text { Watertightness } \\
\text { (EN 12390-8) }\end{array}$ & XV1(H) - XV2(H) (MSZ 4798) & n.t. & n.t. \\
\hline $\begin{array}{l}\text { Flexural-tensile strength } \\
\text { (EN 14617-2) }\end{array}$ & n.t. & $1.5-2.5 \mathrm{~N} / \mathrm{mm}^{2}$ & $0.6-0.8 \mathrm{~N} / \mathrm{mm}^{2}$ \\
\hline $\begin{array}{l}\text { Impact resistance } \\
\text { (EN 14617-9) }\end{array}$ & n.t. & $45-55 \mathrm{~mm}$ & $25-30 \mathrm{~mm}$ \\
\hline $\begin{array}{l}\text { Freeze-thaw resistance } \\
\text { (EN 14617-5) }\end{array}$ & n.t. & not resistant & not resistant \\
\hline
\end{tabular}

Table 1. Design parameters and test results (n.t.: not tested property)

1. táblázat Tervezési paraméterek és vizsgálati eredmények (n.t.: nem vizsgált jellemzö) 


\subsection{Second research phase - general}

According to the test results of the second research phase, it can be postulated that the designed mixtures are suitable for indoor vertical covering applications - as mounted panels or as monolithic concrete wall. Freeze-thaw resistance tests showed that the mixtures are not resistant against frost effect, despite of the standard level of only 25 freeze-thaw cycles. Our specimens suffered visible damage after 10 cycles (Fig. 3). After 25 cycles they became inappropriate for any more testing (Fig. 4) (the standard defines frost resistance based on residual flexural-tensile strength). The significant open porosity of the specimens causes excessive water-absorption that makes the mixtures unable to resist against numerous freeze-thaw cycles [14]. The apparent (body) density of the AAC waste based mixtures is about half of that of naturals stones, which are commonly applied in wall coverings (e.g. travertine $2000-2400 \mathrm{~kg} / \mathrm{m}^{3}$, granite $2500-2800 \mathrm{~kg} / \mathrm{m}^{3}$ ). It results much smaller scale of mounting assemblies. According to thermal conductivity test results, the designed artificial stone mixtures are hand warm to touch. Moreover, considering their moisture absorption capacity, the panels are able to store $15-20 \mathrm{~m} \%$ moisture from the air. These two attributions make the panels ideal to maintain comfortable indoor air condition. According to flexural tensile strength and impact resistance [15], it is ideal for covering panels. In the moment of failure, the intersection does not cracks through, the panel remains in one piece. It is advantageous, because there is no falling debris, which may cause collateral damage, or personal injuries.

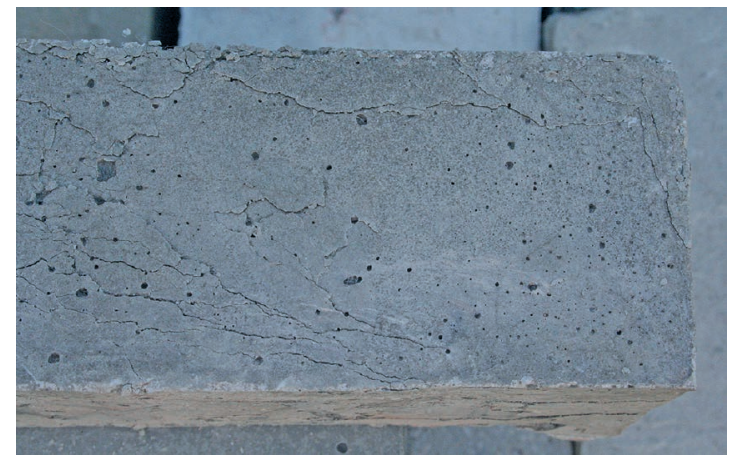

Fig. 3. Damaged specimen after 10 freeze-thaw cycles

3. ábra Próbatest károsodása 10 fagyasztás-olvasztás ciklust követöen

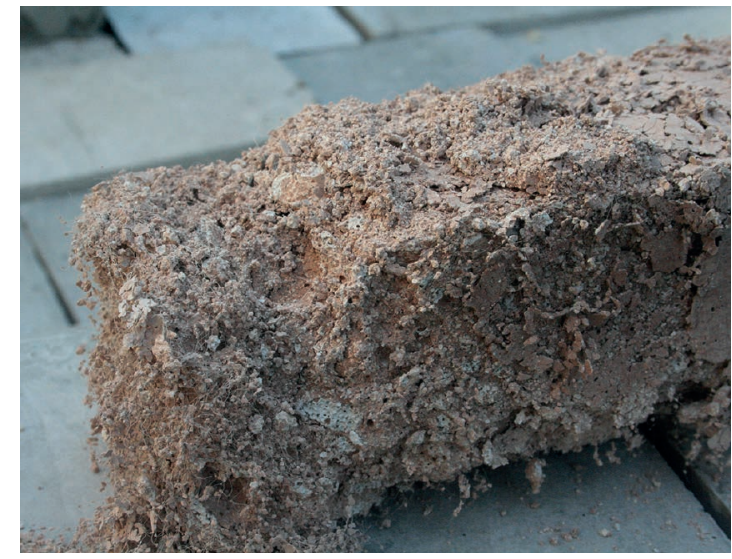

Fig. 4. Damaged specimen after 25 freeze-thaw cycles

4. ábra Próbatest károsodása 25 fagyasztás-olvasztás ciklust követöen

\subsection{Chemical reactions in white cement mixtures - second} research stage

In the second research phase, two mixing stages were performed. After preparing the mixtures for the first stage, the specimens made with white cement became unsuitable for testing. At the age of 28 days (all specimens were stored under water from the day of demolding) it was visible that the hardening has not been completed. The specimens were peeling in touching by hand (Fig. 5). It was generally assumed that the used white cement was too old, therefore, unsuitable for concrete mixing (the specimens, made with fresh grey cement were appropriate, and were tested without problems). Therefore, the mixtures with fresh white cement were mixed again in the second mixing stage. The new specimens became suitable for mechanical testing, except one mix (with the highest cement dosage). That one showed the same look and damage than the ones in the first mixing stage. The test result of suitable specimens showed significantly lower values in all tests than the Portland cement (grey) mixtures. The results suggested that some unexplored chemical transformation occurs inside the specimens.

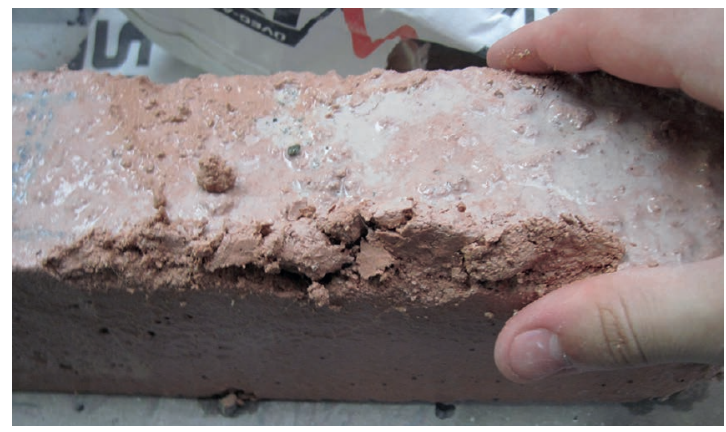

Fig. 5. White cement mixtures peeling in hand

5. ábra Fehér cementtel készült próbatest kézben mállik

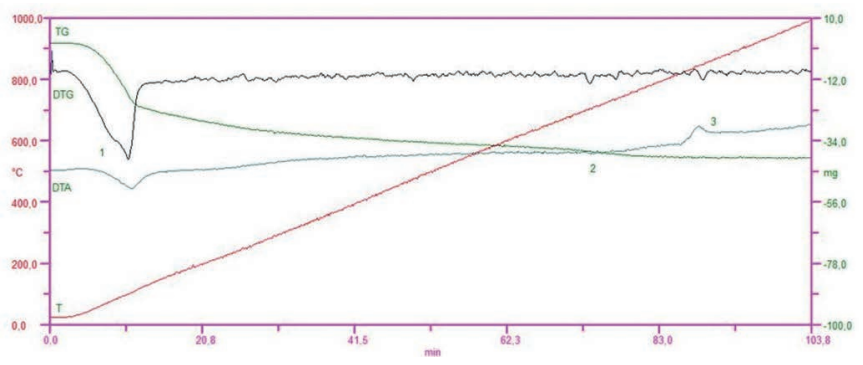

Fig. 6. Differential thermal analysis of AAC

6. ábra Pórusbeton derivatogramja

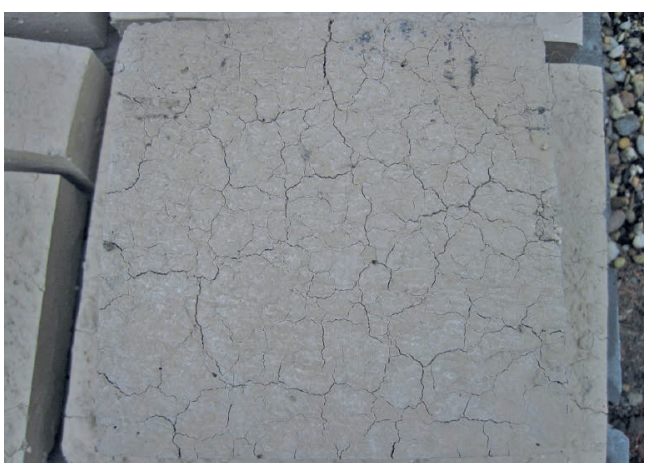

Fig. 7. Map-like cracks

7. ábra Térképszerü felületi repedések 
To explore this reaction, differential thermal analyses (derivatograhpy) have been made on the AAC waste, on the coloring pigments, and on the hardened concrete as well. The TG-DTG-DTA curves of the AAC showed that the raw material contains approximately 10-12 m\% gypsum (Fig. 6). The map-like cracks on the surface of the specimens (Fig. 7) indicated that we some kind of swelling reaction occurs connected to the gypsum content. The permissible maximum acid-soluble sulphate content of recycled concrete aggregates according to the DIN 4226-100:2002 standard and the DAfStbRichtlinie (2010) technical specification is $0.8 \mathrm{~m} \%$ [16]. In the aggregate tested in our experiments this value was higher, due to the gypsum content. The aluminate modulus (AM) of the used cement was $A M>17$. AM is one indicator for the predisposition of the cement to sulfate corrosion. The AM of normal Portland cements is $\mathrm{AM}=1.0-2.5$. The AM of sulfate resistant Portland cements is $\mathrm{AM}<0.64$, for moderate sulfate resistant Portland cements is $\mathrm{AM}<1.0$. If $\mathrm{AM}$ is above 1.0, it increases the intensity of formation of a clinker mineral, called tricalcium-aluminate. Tricalcium-aluminate $\left(3 \mathrm{CaO} \cdot \mathrm{Al}_{2} \mathrm{O}_{3}\right.$, commonly known as felite; silicate chemical nomenclature: $\mathrm{C}_{3} \mathrm{~A}$ ) is a fast set clinker mineral, with high heat of hydration, and may result a concrete mixture unsuitable for placing due to the fast formation of calcium-aluminate-hydrate:

$$
3 \mathrm{CaO} \cdot \mathrm{Al}_{2} \mathrm{O}_{3}+\mathrm{Ca}(\mathrm{OH})_{2}+12 \mathrm{H}_{2} \mathrm{O}=4 \mathrm{CaO} \cdot \mathrm{Al}_{2} \mathrm{O}_{3} \cdot 13 \mathrm{H}_{2} \mathrm{O}
$$
(calcium-aluminate-hydrate)

Moreover, the calcium-aluminate-hydrate formed has very low strength, so this reaction may completely ruins microstructure of concrete. This is the reason why cement factories add gypsum to the clinker, since $\mathrm{C}_{3} \mathrm{~A}$ reacts with the gypsum, and a new phase, trisulphate (or ettringite) is formed:

$$
\begin{aligned}
& 3 \mathrm{CaO} \cdot \mathrm{Al}_{2} \mathrm{O}_{3}+3 \mathrm{CaSO}_{4} \cdot 2 \mathrm{H}_{2} \mathrm{O}+26 \mathrm{H}_{2} \mathrm{O}= \\
& 3 \mathrm{CaO} \cdot \mathrm{Al}_{2} \mathrm{O}_{3} \cdot 3 \mathrm{CaSO}_{4} \cdot 32 \mathrm{H}_{2} \mathrm{O} \text { (ettringite) }
\end{aligned}
$$

Ettringite is a mineral of relatively large in size due to the 32 moles crystallization water in its structure, and the crystallization pressure during formation can reach $100 \mathrm{~N} / \mathrm{mm}^{2}$. This is not a problem, if the genesis of the crystals occurs while the concrete mixture is still plastic, and is able to be deformed. It is assumed that in our case, the production of ettringite was shifted in time, and still formed, when the strength holding tricalcium-silicate $\left(3 \mathrm{CaO} \cdot \mathrm{SiO}_{2}\right.$ commonly known as alite; silicate chemical nomenclature: $\mathrm{C}_{3} \mathrm{~S}$ ) minerals started to generate the calcium-silicate-hydrate products in the hydration process. If our presumption is correct, then the crystallization pressure of ettringite crystals destroys the bonding between the $\mathrm{C}_{3} \mathrm{~S}$ hydration products, and this way the hardening process of the concrete is damaged. In order to verify our assumption, X-ray diffraction analysis was carried out. On the XRD images of the 1-day-old samples both anhydrite (Fig. 8) and ettringite (Fig. 9) were detected. Comparing the XRD images of ettringite, made on 1-day-old and 7-day-old samples, it was proved that the amount of ettringite has been increased (Fig. 10 - solid line is the 1-day-old sample, dotted line is the 7-day-old sample). For further proofing, swelling has also been measured on fresh samples from 1 to 7 days of age (Fig. 11). Samples JT1, JT2, JT3 were cured on air under permanent climatic conditions. Samples JT4, JT5 were cured under water. Another finding is that under water the samples have swollen almost the double that of the samples cured on air. This is due to the curing water supply for hydrate genesis (from anhydrite), which maintains the formation of ettringite.

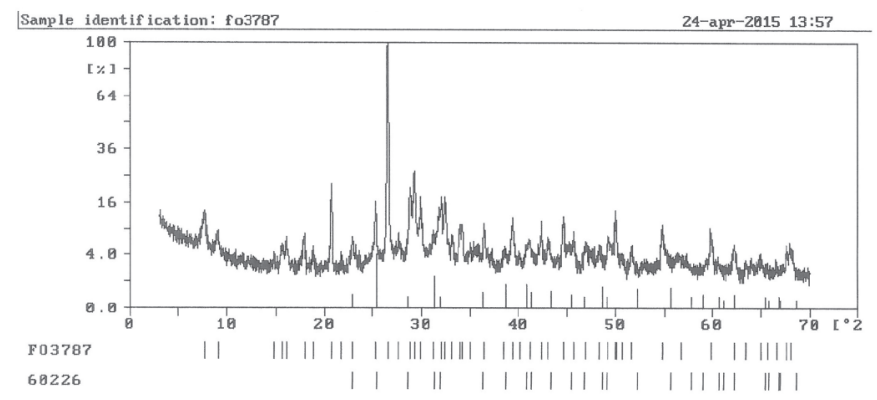

Fig. 8. XRD images with the lines of anhydrite

8. ábra Röntgendiffraktogram anhidrit csúcsokkal

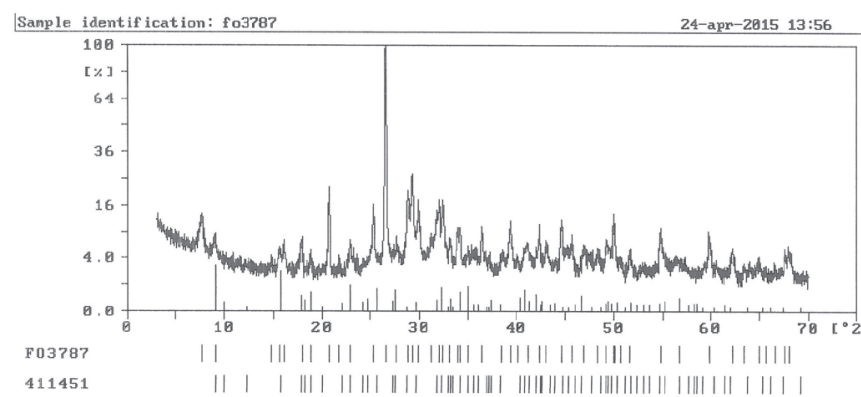

Fig. 9. XRD images diffraktogramm with the lines of ettringite

9. ábra Röntgendiffraktogram ettringit csúcsokkal

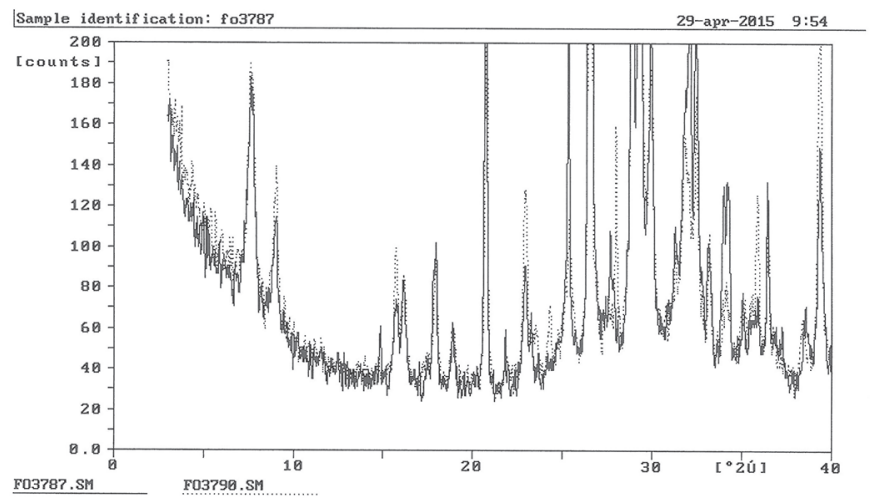

Fig. 10. XRD images with the lines of andydrite at the age of 1 and 7 days 10. ábra Röntgendiffraktogram anhidrit csúcsokkal 1 és 7 napos korban

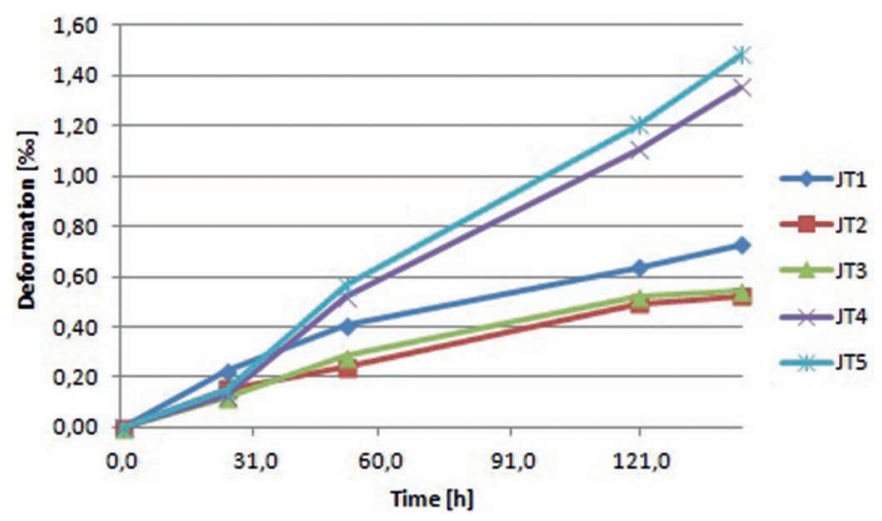

Fig. 11. Swelling on fresh samples

11. ábra Friss minták duzzadása 


\section{Conclusions}

During our research, lightweight aggregate concrete with crushed autoclaved aerated concrete (AAC) waste aggregate was prepared. The mixtures were tested in two different research phases, both for different purposes of use. Their suitability for the planned use was confirmed by laboratory tests according to the Hungarian and European standards.

In the first research phase, mixtures were designed for vertical load bearing and insulation purpose. Our test results confirmed the suitability for this application. We recommend using the mixtures for the preparation of building blocks. Required mortar for masonry work can be produced from fine-grained crushed AAC waste as well. The advantage to reinforced concrete is the low apparent (body) density and low thermal conductivity. Unlike other building blocks on the market, the watertightness of the mixtures tested is beneficial. Therefore, the tested LWAC mixtures can be applied in subsoil parts of buildings, while none of the commercially available building block families are suggested for this.

In the second research phase, the mixtures were designed for vertical covering purpose. The test results confirmed the suitability only for indoor application. They can be used as covering panels, or as monolithic concrete walls. The designed mixtures showed many advantages. If used as panels, their low apparent (body) density generates savings in the costs of the mounting equipments, and generates less load on the structures - compared to the commonly used natural covering stones. Low thermal conductivity and excessive moisture absorption capacity makes it ideal to maintain comfortable indoor air condition. According to flexural tensile strength and impact resistance, it is ideal for the preparation of covering panels. A chemical reaction between AAC aggregate and white cement was revealed. Considerable swelling is observed due to delayed ettringite formation damaging the solid mineral phases, with a strong effect of curing on the reaction. Specimens cured underwater swollen double in magnitude than specimens cured on air in climate chamber.

\section{Acknowledgement}

Authors acknowledge that specific materials were provided for the laboratory tests by the support of the OTKA K 109223 research project (Hungarian Scientific Research Fund, OTKA).

\section{References}

[1] 2000/532/EC commission decision on waste list

[2] 45/2004. (VII. 26.) BM-KvVM együttes rendelet az építési és bontási hulladék kezelésének részletes szabályairól (decree about the detailed rules of handling building industrial waste; in Hungarian)

[3] 2012. évi CLXXXV. törvény a hulladékról (law about waste; in Hungarian)

[4] Hoffmannm L. - Józsa, Zs. - Nemes R. (2003): Üveghulladékból könnyübeton adalékanyag, Épitöanyag, Vol. 55, No 1, pp. 13-17. http://dx.doi.org/10.14382/epitoanyag-jsbcm.2003.3

[5] Nemes, R. (2015): Surface properties of lightweight aggregate concrete and its correlation with durability, Materials Science Forum Vol. 812, pp. 207-212. http://dx.doi.org/10.4028/www.scientific.net/MSF.812.207

[6] Józsa, Zs. - Nemes, R. (2002): Recycled Glass Aggregate for Lightweight Concrete, Concrete Structures Vol. 3, pp. 41-46.

[7] Schoon, J. - De Buysser, K. - Van Driessche, I. - De Belie, N. (2013): Feasibility study on the use of cellular concrete as alternative raw material for Portland clinker production, Construction and Building Materials Vol. 48, pp. 725-733. http://dx.doi.org/10.1016/j.conbuildmat.2013.07.083

[8] Boehme, L. (2013): Recycled Aerated Concrete Aggregates, Proceedings of Traditional Screed for Floorings in Central Europe towards Sustainable Building 2013 Low-tech and high-tech materials and technologies for Sustainable Buildings. pp. 1-8.

[9] Bergmans, J. - Nielsen, P. - Jacobs, K. - Broos, K. (2012): Recycling of cellular concrete: turning a weakness into a strength, Innovative Strategies for High-Grade Material Recovery from Construction and Demolition Waste Conference (oral presentation) VITO, Flemish Institute for Technological Research, Mol, Belgium

[10] Ujhelyi, J.(1960): A könnyűadalékos beton fajtái, összetételének tervezése és a beton készítése; Felsőoktatási Jegyzetellátó Vállalat, Budapest, 2 p. (Types, design of composition, and mixing of lightweight aggregate concrete; in Hungarian)

[11] Kozák, J. - Magyari B.(2013): A budapesti négyes metróvonal építése 4: FRC burkolatok a négyes metró három állomásán, Budapesten, Vasbetonépités, Vol 15, No. 2, pp. 53-56 (Building Budapest Metro line four, Part 4: FRC coverage, applied at three stations; in Hungarian)

[12] Magyari, B. (2005): Fibre reinforced concrete elements applied on facades, Proceedings of the Keep concrete attractive- fib Symposium, Vol. 1, pp. 8691.

[13] Kozák, J. - Magyari, B. - Tassi G. (2011): PPFRC cornice and wall covering, Proceedings of the Innovative Materials and Technologies for Concrete Structures - Central European Congresson Concrete Engineering, pp. 393-396.

[14] Nemes, R. (2015): Könnyübetonok fagyasztásvizsgálatának érdekességei, Építőanyag - Journal of Silicate Based and Composite Materials, Vol. 67. No. 1 http://dx.doi.org/10.14382/epitoanyag-jsbcm.2015.6

[15] Nemes, R. (2013): Könnyúbetonok koptatóhatással szembeni ellenállása, Építőanyag, Vol. 65. No. 2, pp. 44-47.

http://dx.doi.org/10.14382/epitoanyag-jsbcm.2013.10

[16] Kausay, T. (2013): Beton (Concrete) Mérnöki Kamara Nonprofit Kft., Budapest, ISBN: 978-963-88358-4-0

$\underline{\text { Ref.: }}$

Fenyvesi, Olivér - Jankus, Bence: Opportunities in recycling AAC waste as aggregate for lightweight concrete Építỏanyag - Journal of Silicate Based and Composite Materials, Vol. 67, No. 2 (2015), 66-70. p. http://dx.doi.org/10.14382/epitoanyag-jsbcm.2015.11

Újrahasznosított pórusbeton alkalmazási lehetőségei könnyübeton adalékanyagaként

A tudatos hulladék-gazdálkodás, és ezen belül az építési hulladékok lerakott mennyiségének csökkentése, újrafelhasználása, illetve újrahasznosítása egyre fontosabbá válik világszerte. Önálló kategóriaként kb. 15 éve jelent meg az építési-bontási hulladék jogszabályainkban, mely szintén e kutatási téma fontosságát jelzi. Kutatásunk során a pórusbeton és gázbeton hulladékok újrahasznosításával foglalkozunk. A mai napig két kutatási fázist fejeztünk be ebben a témában, de további kísérletek végzését tervezzük a jövôben. Fố célunk az építôiparban is használható könnyúbeton keverékek elōállítása pórusbeton hulladék felhasználásával. Az elsố kutatási fázis során teherviselô és hôszigetelố funkciójú betonkeverékeket vizsgáltunk. Második kutatási fázisunkban pedig függôleges burkolathoz készítettünk könynyúbetont, zúzott pórusbeton adalékanyaggal. Laboratóriumi vizsgálatainkat a hatályos európai és Magyar szabványok szerint végeztük.

Kulcsszavak: Pórusbeton, gázbeton, építési-bontási hulladék, újrahasznosítás, könnyúbeton 